leña, el Rastro, el comic, lo kitscb), actores (mujeres, más mujeres, mayores y niños) y la evolución cinematográfica, Pedro Almodóvar y la historia del cine español, y un recuento de la mayoría de las críticas hechas a nuestro autor.

La primera parte es más sustanciosa, al menos por sus pretensiones de Sociología de una biografía. Intento de refiejar una sociedad a partir de una figura televante: la España Cañí descubierta (o inventada) a partir del cine de Almodóvar.

Dividida en tres partes, en la primera se dedica a dar cuenta de los elementos biográficos del autor, elementos que le dan este toque diferente, almodovariano: su procedencia tural, la infuencia de la cultura religiosa, autodidactismo, Telefónica, el bolero, la coyuntura y el contexto social urbano madrileño, y la cultura publicitaria. En la segunda parte, y a partir del análisis realizado en la primera, descompone la sociedad española a través del cine de Pedro Almodóvar, o, como ella misma subtitula, «o hagamos un puzzle con sus tipos y sus cosas»; entre los cuales destacan; las madres, «co. nejos y gallinas y algún que otro animal», Jas novias casamenteras, los tele. diarios almodovarianos y los detergentes. Y.a en la tercera parte analiza la sociedad madrileña de los años ochenta, cuyo punto de partida es el contexto sociocultural del cine de Almodóvar.

Si bien la primera impresión del libro es de divertimento (que sí se consigue), el regusto al finalizar la lectura es de quedar demasiadas cosas por contestar, apunta hacia muchas direcciones que no aclara, y, en sí, adolece de dar una visión global y completa.

\title{
Teresa Samper
}

Lamo de Espinosa, Emilio,

Delitos sin victima. Orden social y ambivalencia moral, Ed. Alianza Universidad, Madrid, 1989.

Uno de los objetivos más significativos del presente libro es demostrar que la desviación, la inmoralidad o el desorden constituyen parte esencial del mismo orden social que parecen rechazar. El autor cree que la desviación es parte del orden y no su ruptura, y que, como tal, debe constituir objeto del análisis teórico; se plantea, asimismo, que la microsociología debe recoger la desviación y erigirla en el centro de su análisis.

Delitos sin victima. Orden social y ambivalencia moral, es una apuesta arriesgada en el sentido de que el autor reformula y se enfrenta a aquellos parámetros de la sociología y del derecho en los que el orden social y por extensión la moralidad pública se convertían en el centro de una Teoría que 
tenía y tiene, en la mayoría de los casos, como última finalidad el mantenimiento de un determinado statu quo. Lamo de Espinosa arremete, por tanto, contra los fundamentos de la sociología funcionalista y de la ideología penal conservadora.

Otro tema interesante que analiza el autor es el de la victimización. El consumo de drogas, la prostitución o ciertas conductas sexuales son comportamientos punibles en numerosas legislaciones, si bien la presunta victima no sólo consiste sino que busca activamente tal servicio. Lamo de. Espinosa apunta que la paradoja que supone la existencia de delitos sin víctima se explica por el hecho de lo que se sanciona son conductas que atentan contra la moralidad pública, y por ello son de gran valor para analizar las relaciones entre la lógica social, la moral dominante y la eficacia represora del Derecho penal.

El libro que reseñamos es, en palabras de su propio autor, una refundición y síntesis de diversos trabajos, algunos de los cuales habían ya sido publicados; con esta refundición el autor pretende dar una unidad y coherencia, sobre todo en lo que hace referencia a la conceptualización y construcción del marco teórico, a sus estudios para poder abordar con éxito el tema que le ocupa: las relaciones entre el orden social y el orden moral y la incidencia del derecho penal en ambos. La elaboración del aparato teórico y conceptual del libro se apoya, en su práctica totalidad, en el interaccionalismo simbólico, en la sociología de la desviación y en la criminología norteamericana.

En el libto no hay investigación empírica, encuestas, entrevistas y trabajo de campo; únicamente en el capítulo segundo, donde se analiza el proceso de criminalización y el consumo de estupefacientes se utilizan este tipo de técnicas analíticas. $\mathrm{Si}$ bien debemos señalar que esta carencia metodológica no es algo que preocupe a su autor, el interés del mismo es, únicamente, la elaboración de modelos teóricos ideal-típicos de pautas de conducta previsibles contrastables en los diversos actores sociales del mundo del «vicio» (policías, delincuentes, opinión pública, etc.), ofreciendo al mismo tiempo una visión crítica acerca del actual Derecho penal.

Francesc Abril 